\title{
Human T-cell leukemia virus type-I Tax induces the expression of CD83 on T cells
}

Yuetsu Tanaka ${ }^{1 *}$, Mariko Mizuguchi ${ }^{2}$, Yoshiaki Takahashi' ${ }^{1}$ Hideki Fujii ${ }^{1}$, Reiko Tanaka' ${ }^{1}$ Takuya Fukushima ${ }^{3}$,

Takeaki Tomoyose ${ }^{4}$, Aftab A Ansari ${ }^{5}$ and Masataka Nakamura ${ }^{2}$

\begin{abstract}
Background: CD83, a cell surface glycoprotein that is stably expressed on mature dendritic cells, can be transiently induced on other hematopoietic cell lineages upon cell activation. In contrast to the membrane form of CD83, soluble CD83 appears to be immunosuppressive. In an analysis of the phenotype of leukemic CD4 ${ }^{+} \mathrm{T}$ cells from patients with adult T-cell leukemia (ATL), we found that a number of primary CD4 ${ }^{+}$T cells became positive for cell surface CD83 after short-term culture, and that most of these $\mathrm{CD} 83^{+} \mathrm{CD} 4^{+} \mathrm{T}$ cells were positive for human T-cell leukemia virus type-I (HTLV-I) Tax (Tax1). We hypothesized that Tax1 is involved in the induction of CD83.

Result: We found that CD83 was expressed selectively on Tax1-expressing human CD4 ${ }^{+} \mathrm{T}$ cells in short-term cultured peripheral blood mononuclear cells (PBMCs) isolated from HTLV-- ${ }^{+}$donors, including ATL patients and HTLV-I carriers. HTLV-l-infected T cell lines expressing Tax 1 also expressed cell surface CD83 and released soluble CD83. CD83 can be expressed in the JPX-9 cell line by cadmium-mediated Tax 1 induction and in Jurkat cells or PBMCs by Tax1 introduction via infection with a recombinant adenovirus carrying the Tax1 gene. The CD83 promoter was activated by Tax 1 in an NF-kB-dependent manner. Based on a previous report showing soluble CD83-mediated prostaglandin E2 (PGE2) production from human monocytes in vitro, we tested if PGE2 affected HTLV-I propagation, and found that PGE2 strongly stimulated expression of Tax1 and viral structural molecules.
\end{abstract}

Conclusions: Our results suggest that HTLV-I induces CD83 expression on T cells via Tax1 -mediated NF-KB activation, which may promote HTLV-I infection in vivo.

Keywords: CD83, HTLV, Tax, ATL, PGE2

\section{Background}

CD83 is a $40-50-k D a$ cell surface glycoprotein that is a member of the sialic-acid-binding immunoglobulin-like lectin family, and is a marker of mature dendritic cells (DCs) in humans and mice [1]. In contrast to mature DCs, which stably express high levels of CD83 [2], previous studies suggest that CD83 is transiently expressed on other hematopoietic cell lineages and tissues, including activated $\mathrm{T}$ cells and $\mathrm{B}$ cells [1,3-5], macrophages [2], neutrophils [6], and NK cells [7] in vitro, and hematopoietic tissues [8] and skin Langerhans cells [1] in vivo.

\footnotetext{
*Correspondence: yuetsu@s4.dion.ne.jp

${ }^{1}$ Department of Immunology, Graduate School of Medicine, University of the Ryukyus, 207 Uehara, Nishihara-cho, Okinawa 903-0215, Japan Full list of author information is available at the end of the article
}

Two isoforms of CD83, a membrane-bound form (mCD83) and a soluble form (sCD83) have been identified; sCD83 is likely a result of shedding the mCD83 isoform [9]. mCD83 critically functions not only in the development of $\mathrm{CD} 4^{+} \mathrm{T}$ cells in the thymus [8], but also in $\mathrm{T}$ cell activation [10] and the longevity of $\mathrm{B}$ and $\mathrm{CD} 4^{+}$ $\mathrm{T}$ cells [4]. In contrast, $\mathrm{sCD} 83$ functions as a suppressor of $\mathrm{T}$ cell activation [11]. A recent study has shown that sCD83 suppresses the differentiation of DCs from monocytes [12]. Elevated levels of plasma sCD83 have been demonstrated in patients with hematological malignancies [13]. Kreiser et al. showed that the in vitro culture of mCD83-expressing fresh regulatory $\mathrm{T}$ cells in mice leads to the release of sCD83 [14]. Although the molecular mechanisms by which sCD 83 mediates $\mathrm{T}$ cell suppression are not fully understood, human sCD83 may mediate its 
inhibitory effect on $\mathrm{T}$ cell responses via prostaglandin $\mathrm{E} 2$ (PGE2) produced by monocytes [15].

Human T-cell leukemia virus type-I (HTLV-I) is a human retrovirus that is etiologically associated with adult T-cell leukemia (ATL) [16] and HTLV-I-associated myelopathy/tropical spastic paraparesis (HAM/TSP) $[17,18]$. The majority of HTLV-I carriers remain asymptomatic throughout their lives, and approximately 5\% of HTLV-I-infected individuals develop either ATL or HAM/TSP after prolonged latency periods [19]. HTLVI encodes Tax (Tax1), which activates viral transcription and promotes mechanisms that are critical for cell growth and division, leading to viral replication [20]. The effects of Tax 1 on cells include potent NF- $\mathrm{BB}$ activation, cell cycle perturbation, and cell transformation [21]. In addition to Tax1, the basic leucine zipper of HTLV-I (HBZ) has been proposed to play an important role in the oncogenesis of ATL by HTLV-I [22]. However, the precise mechanisms by which HTLV-I infection leads to disease development remain poorly understood.

HTLV-I is transmitted through contact with body fluids containing infected cells; common examples include mother-to-child transmission [19]. It is difficult to detect HTLV-I-antigen-expressing cells in fresh PBMCs from HTLV-I infected individuals. When PBMCs are cultured for a short period of time, some $\mathrm{T}$ cells begin to produce HTLV-I antigens [23] followed by spontaneous immortalization of cells in cultures containing interleukin-2 (IL-2) [24]. CD8 ${ }^{+}$cytotoxic T lymphocyte (CTL) [25] and neutralizing antibody [26] responses specific to HTLV-I play important roles in controlling HTLV-I propagation in HTLV-I carriers. It is noteworthy that not only ATL patients, but also healthy HTLV-I carriers are prone to immunodeficiency [27-31]. Curiously, monocytes from $\mathrm{HTLV}_{-} \mathrm{I}^{+}$donors exhibit a deficiency in the ability to differentiate into mature DCs in vitro, and cultured immature DCs show low levels of CD83 expression in association with poor $\mathrm{T}$ cell stimulation [32].

In an analysis of phenotypes of PBMCs from ATL patients and HTLV-I carriers living in Okinawa prefecture, Japan, where ATL is prevalent, we detected high levels of $\mathrm{CD} 83$ expression in primary $\mathrm{CD}^{+} \mathrm{T}$ cells from PBMCs of HTLV-I ${ }^{+}$donors after short-term in vitro culture. Surprisingly, most of these $\mathrm{CD} 83^{+}$cells from HTLV$\mathrm{I}^{+}$donors were positive for Tax 1 . Herein, we show that Tax1 is responsible for the induction of CD83 on T cells, and discuss its possible role(s) in HTLV-I infection.

\section{Results}

\section{CD83 expression on $\operatorname{Tax} 1^{+}$cells}

In a phenotypic analysis of fresh and in vitro cultured PBMCs from ATL patients in Okinawa, we noticed that short-term cultivation induced CD83 expression in a subpopulation of $\mathrm{CD}^{+} \mathrm{T}$ cells in PBMCs (Figure 1a, b). Interestingly, a majority of the CD83-positive $\mathrm{CD} 4^{+}$ $\mathrm{T}$ cells exhibited detectable levels of intracellular Tax1 expression. The Tax1 expression in cultured PBMCs from ATL patients was confirmed by a western blot analysis with our anti-Tax1 monoclonal antibody (mAb) (Lt4) (Additional file 1: Figure S1). Similar acquisition of CD83 on Tax $1^{+}$cells was observed in cultured PBMCs from HTLV-I carriers and HAM/TSP patients (data not shown). In contrast, only low levels of CD83 expression were observed in normal PBMCs cultured in vitro without mitogen. Cultures with mitogen exhibited increased CD83 expression in a small population of $\mathrm{CD}^{-}$PBMCs (Figure 1c), which were predominantly $\mathrm{CD} 19^{+}$(data not shown), indicating that those $\mathrm{CD} 83^{+}$cells were $\mathrm{B}$ lymphocytes.

We next examined CD83 expression with a panel of $\mathrm{HTLV}^{+} \mathrm{I}^{+} \mathrm{T}$ cell lines. All of the Tax $1^{+}$cell lines tested, including the IL-2-independent $\mathrm{T}$ cell lines (MT-2, HUT102, and MT-1) and IL-2-dependent $\mathrm{T}$ cell lines derived from an ATL patient (ATL-026), a HAM/TSP patient (ILT-M1), or a healthy donor whose $\mathrm{T}$ cells were transformed in vitro by HTLV-I (YT/cM1), were positive for CD83 (Figure 2a). It is noteworthy that an ATL patient-derived HTLV-I-infected T cell line that lacks Tax1 expression (TL-Om1) was negative for CD83 expression. In addition, the $\mathrm{HTLV}_{-} \mathrm{I}^{+}$rat $\mathrm{T}$ cell line W7TM-1, and the human HTLV-II ${ }^{+} \mathrm{T}$ cell line Ton1 were also positive for rat and human CD83, respectively (Figure $2 \mathrm{~b}$ ). The HTLV-I-negative human $\mathrm{T}$ cell lines CEM, Molt-4, and Jurkat and the HIV-1-producing Molt4/IIIB were negative for CD83 (data not shown). CD83 expression thus appeared to parallel the expression of Tax1. These results suggest a relationship between CD83 and Tax1 expression.

The expression of CD83 in HTLV-I ${ }^{+}$cells was confirmed by western blot analyses using our laboratoryderived $\mathrm{mAb}$ (rat IgG, clone W83\#8). As shown in Figure 3, the apparent molecular weight (MW) of the major CD83 molecule in HTLV-I ${ }^{+}$HUT102 cells was $48 \mathrm{kDa}$, which was comparable to that of ectopically expressed CD83 on 293T cells (293T/CD83). Since the protein core of CD83 has an estimated MW of $21 \mathrm{kDa}$ and is heavily glycosylated [9], we inferred that the other CD83-specific bands ranging between 40 and $70 \mathrm{kDa}$ may be CD83 isoforms with different levels of glycosylation.

We next examined the production of sCD 83 by HTLV-I ${ }^{+}$T cells. Levels of CD83 in cell lysates and culture supernatants were quantitated using a commercial enzyme-linked immunosorbent assay (ELISA) kit. All $\mathrm{Tax}^{+} \mathrm{T}$ cell lines tested produced readily detectable levels of sCD83 in culture supernatants (Figure 4). The relative levels of $\mathrm{sCD} 83$ were estimated at approximately 
a

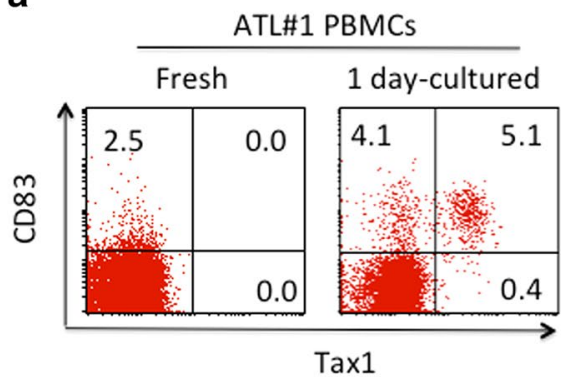

C

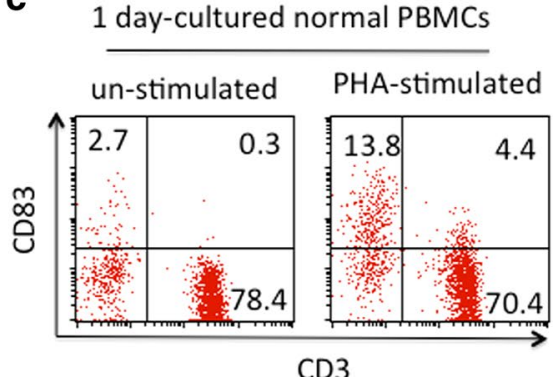

$\mathrm{CD} 3$

b

1 day-cultured ATL PBMCs

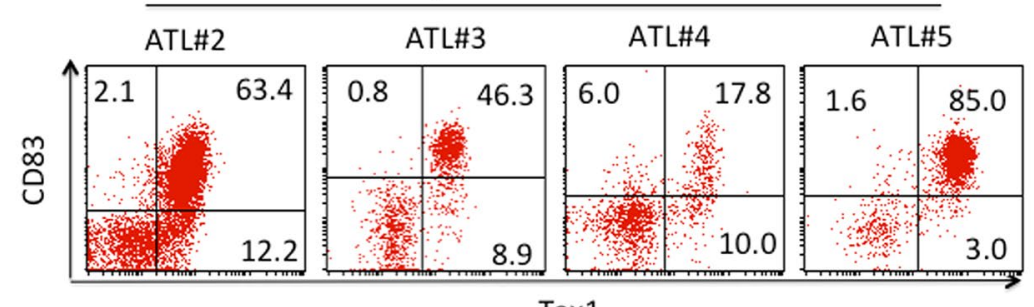

$\operatorname{Tax} 1$

Figure 1 Flow cytometric analysis (FCM) of CD83 expression on primary CD4 ${ }^{+}$T cells expressing Tax1. a, b Lymphocytes were gated based on FSC and SSC in peripheral blood mononuclear cells (PBMCs) derived from adult T cell leukemia (ATL) patients (ATL\# 1 to \#5) and examined for expression of CD83 and Tax1 before or after a 1-day culture. Most ATL patient-derived PBMCs consisted of leukemic CD4+ T cells (data not shown). c Lymphocytes in PBMCs from normal donors were examined for CD83 expression after a 1-day culture in the presence or absence of phytohemagglutinin (PHA). Representative profiles are displayed.

$10-20 \%$ of CD83 levels associated with cells. Since plasma sCD83 is elevated in some patients with chronic lymphocytic leukemia [33], we attempted to determine the levels of sCD83 in plasma samples obtained from acute ATL patients. Out of 11 ATL samples, only one showed a significantly higher sCD83 level $(>1,000 \mathrm{pg} / \mathrm{ml})$ than normal $(<20 \mathrm{pg} / \mathrm{ml})$ (data not shown).

\section{CD83 induction by Tax 1}

The potential ability of Tax 1 to induce CD83 expression was examined using the Tax1-inducible human $\mathrm{T}$ cell line JPX-9. Incubation with $\mathrm{CdCl}_{2}$, which is required for Tax1 expression, induced apparent cell surface CD83 expression on JPX-9 cells (Figure 5a). Importantly, CD83 expression was predominantly restricted to $\mathrm{Tax}^{+}$cells. The majority of $\operatorname{Tax}^{+}$cells also expressed OX40, a representative protein that is also induced by Tax 1 on $\mathrm{T}$ cells [34].

To confirm the Tax1-mediated CD83 expression, CD83 mRNA levels were quantitated by real-time PCR using peripheral blood mononuclear cells (PBMCs) and Jurkat cells following infection with recombinant adenovirus encoding Tax1 (Figure 5b). CD83 mRNA levels were significantly elevated in both PBMCs and Jurkat cells. These results are consistent with the concept that Tax1 induces cell surface expression of CD83, and suggest that the effect of Tax 1 on CD83 expression occurs at the transcriptional level. Taken together, these data strongly imply that CD83 is a member of the HTLV-I Tax-inducible protein family.

\section{Enrichment of live $\operatorname{Tax} 1^{+}$and $\operatorname{Tax} 1^{-}$cells by cell sorting}

It may be noteworthy that the triple-positive (Tax $1^{+}$ $\mathrm{CD} 83^{+} \mathrm{OX}_{40}{ }^{+}$) phenotype was found in primary $\mathrm{CD} 4^{+}$ $\mathrm{T}$ cells from an ATL patient (Figure 6). Generally, IL2-dependent HTLV-I-infected $\mathrm{T}$ cell lines derived from HTLV-I ${ }^{+}$donors consist of HTLV-I antigen-positive and -negative cells, especially during the early culture stage with low passages. Flow cytometry-based cell sorting cannot separate live Tax $1^{+}$cells from live Tax $1^{-}$ cells owing to intracellular localization of Tax1. Based on the present finding that most $\mathrm{Tax}^{+}$cells expressed both CD83 and OX40, we attempted to sort live Tax $1^{+}$ and Tax $1^{-}$cells. An IL-2 dependent HTLV-I ${ }^{+}$T cell line (OKH4) from a HAM/TSP patient was stained with antiOX40 and anti-CD83 mAbs, and subjected to cell sorting. $\mathrm{CD} 3^{+} \mathrm{OX} 40^{+}$sorting efficiently enriched the Tax $1^{+}$ cell population (Figure 7). Similar enrichment of $\mathrm{Tax}^{+}$ cells was obtained with three IL-2-dependent HTLV-I ${ }^{+} \mathrm{T}$ cell lines (data not shown). This strategy would be useful for further studies on Tax1 function in PHTLV-I-infected primary $\mathrm{T}$ cells. 


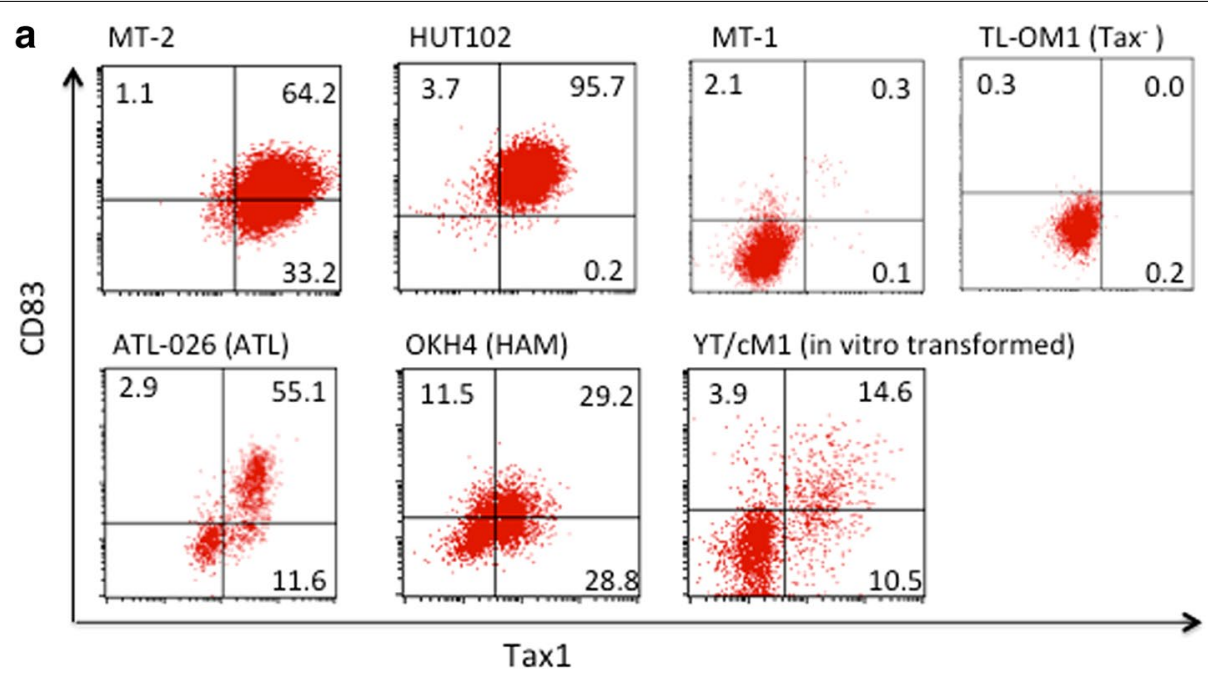

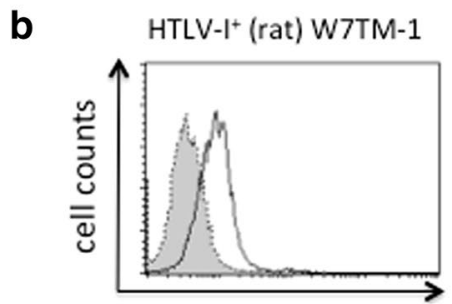

Rat CD83

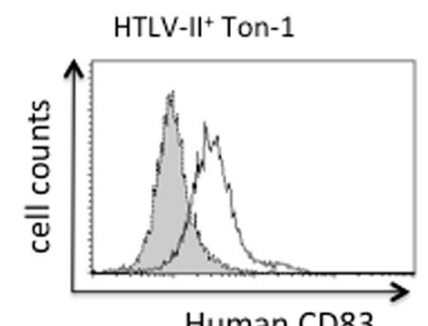

Human CD83

Figure 2 CD83 expression on HTLV-I ${ }^{+}$and HTLV-II+ T-cell lines. a HTLV-I ${ }^{+}$T cell lines (MT-2, HUT102, MT-1, and TL-Om1), and IL-2-dependent T cell lines generated from an ATL patient (ATL-026, $\mathrm{CD} 4^{+}$), a HAM/TSP patient $\left(\mathrm{OKH} 4, \mathrm{CD} 8^{+}\right.$), and a normal donor (in vitro-transformed $\mathrm{YT} / \mathrm{CM} 1, \mathrm{CD} 4^{+}$) were examined for CD83 and Tax1 expression by FCM. Note that the TL-Om1 cell line is negative for Tax1. b Rat and human CD83 expression levels on the rat CD4 ${ }^{+} \mathrm{Tax}^{+}{ }^{+} \mathrm{T}$ cell line (W7TM-1) and the human HTLV-II+ $\mathrm{T}$ cell line (Ton1), respectively, were analyzed by FCM.

Tax1-responsive elements in the CD83 promoter

To gain insight into the molecular mechanism of Tax1dependent induction of CD83, the CD83 promoter was examined by reporter assays. Jurkat cells were transfected with a luciferase reporter plasmid, pCD83(-537) Luc, carrying the isolated wild-type CD83 promoter along with the Tax1 expression plasmid. The CD83 promoter was profoundly activated by Tax1 (Figure 8a). In efforts to localize the CD83 promoter sequences with biological activity, reporter assays were performed using a series of $5^{\prime}$ deletion constructs of the CD83 promoter. These studies showed that pCD83(-101)Luc retained activity to promote transcription in response to Tax1, similar to pCD83(-537)Luc, while pCD83(-29)Luc did not respond to Tax1 (Figure 8a). The observations indicate that a Tax1-responsive element(s) in the CD83 promoter is located in the region between -101 and -30 . A computer search identified two possible NF- $\kappa B$ binding sites between the -101 to -30 region of the CD83 promoter (Figure $8 \mathrm{~b}$ ). We next investigated the potential role of those NF- $\kappa$ B binding sites in Tax1-mediated activation of CD83 gene transcription. This objective was achieved using substitution mutations that were introduced to either each of the possible NF- $\mathrm{kB}$ binding sites or to both sites (Figure 8c). Upon expression of Tax1, each single mutant showed an approximate $50 \%$ decrease in promoter activity compared with the wild-type CD83 promoter (Figure $8 \mathrm{~d}$ ). Little, if any, response to Tax1 was observed for the mutant pCD83(-537 кBmt1/2)Luc carrying mutations at both sites (Figure $8 \mathrm{~d}$ ).

The Tax1-mediated upregulation of CD83 expression via NF- $\mathrm{kB}$ activation was verified by reporter assays on a series of Tax1 mutants. All Tax1 mutants except for TaxM22, which lacks the NF- $\mathrm{KB}$ activation function, facilitated CD83 promoter activity (Figure 9). TaxM22 did not show significant induction of luciferase activity from pCD83(-537)Luc. Collectively, these results demonstrate that the two NF- $\mathrm{kB}$ binding sites are critical for the induction of CD83 expression in response to Tax1. HTLV-II Tax2B also upregulated CD83 promoter activity, consistent with cell surface expression of CD83 by the HTLV-II $^{+}$cells (Figure 2b). 


\begin{tabular}{|c|c|c|c|c|c|c|c|c|}
\hline \multirow[t]{2}{*}{1} & 2 & 3 & 4 & 5 & 6 & 7 & 8 & $(\mathrm{MW})$ \\
\hline & 96 & & 3esth & & & & & $\begin{array}{l}-250 \mathrm{kDa} \\
-150 \\
-100 \\
-75 \\
-50 \\
-37 \\
-25 \\
-15\end{array}$ \\
\hline \multicolumn{4}{|c|}{$\begin{array}{l}\text { Detection with } \\
\text { Anti-CD83 mAb }\end{array}$} & An & HIV & on $\mathrm{n}$ & $\begin{array}{l}\text { th } \\
\mathrm{mAb}\end{array}$ & \\
\hline \multicolumn{9}{|c|}{$\begin{array}{l}\text { Figure } 3 \text { Western blot analysis of CD83 expressed in the HTLV-I }{ }^{+} \\
\text {T cell line HUT102. Cell lysates from control 293T/CT (lanes } 1 \text { and 5), } \\
\text { CD83-transfected 293/TCD83 (lanes } 2 \text { and 6), CEM (lanes } 3 \text { and 7), and } \\
\text { HUT102 (lanes } 4 \text { and 8) were subjected to sodium dodecyl sulfate } \\
\text { polyacrylamide gel electrophoresis (SDS-PAGE) on a 5-20\% gel, and } \\
\text { blotted onto PVDF membranes. The membranes were incubated } \\
\text { with either rat anti-human CD83 monoclonal antibody (mAb) (clone } \\
\text { W\#83-8, lanes 1-4) or isotype control rat IgG (clone WAP-24, lanes 5-8) } \\
\text { antibody, followed by treatment with HRP-labeled goat anti-rat lgG } \\
\text { antibody. }\end{array}$} \\
\hline
\end{tabular}

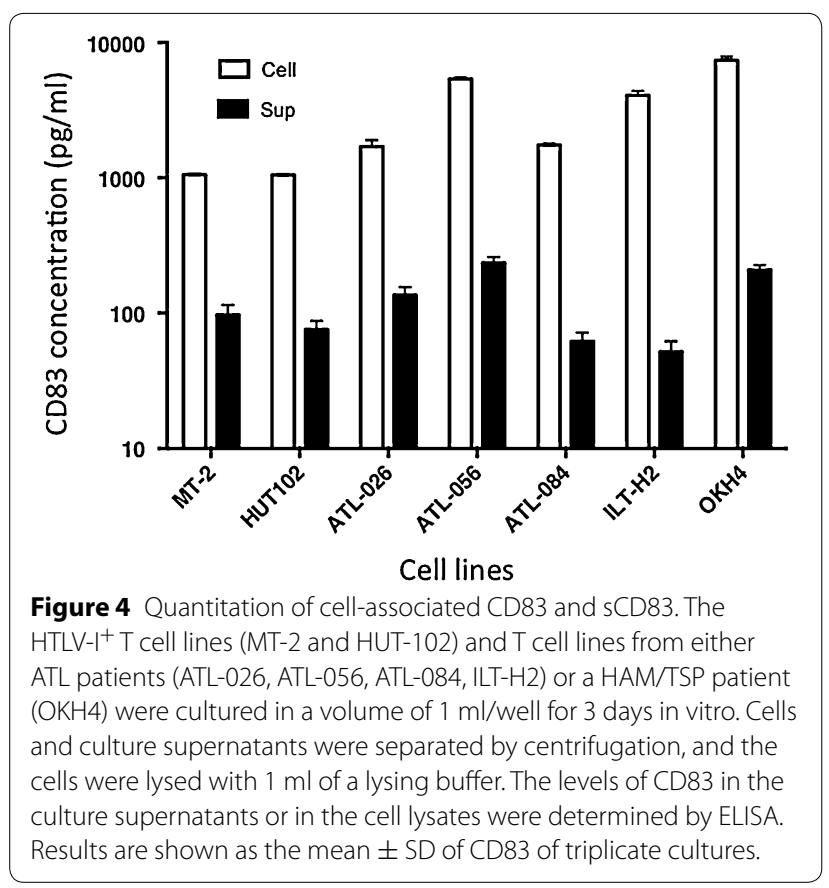

\section{Stimulation of Tax 1 expression and HTLV-I production by PGE2}

sCD83 has been reported to stimulate PGE2 production from human monocytes and to suppress $\mathrm{T}$ cell activation in vitro [15]. We thus tested the effects of PGE2 on HTLV-I expression in an ATL-derived HTLV-I ${ }^{+}{ }^{+}$cell line (ATL-056). PGE2 induced marked expression of Tax1 (Figure 10a). In addition, we observed an increase in expression of the viral envelope protein gp46 and release of viral core protein p24 to the culture supernatants (Figure 10a). Figure 10b shows that PGE2 treatment increased the syncytium-inducing activity of ATL-056 cells, suggesting that PGE2 enhances cell-to-cell infectivity of HTLV-I.

\section{Discussion}

In the present study, we showed for the first time that CD83 is expressed by Tax $1^{+}$cells in primary cultures of $\mathrm{CD} 4^{+} \mathrm{T}$ cells and HTLV-I- or HTLV-II-infected CD4 ${ }^{+}$ or $\mathrm{CD}^{+} \mathrm{T}$ cell lines. Fresh ATL leukemic T cells express CD2, CD5, CD4, CD25, CD29, CD40RO, CD194, T cell receptor $\alpha / \beta$, and HLA-DR with diminished CD3 expression [35], but they do not express Tax1. Cultures of primary CD4 ${ }^{+} \mathrm{T}$ cells from $\mathrm{HTLV}-\mathrm{I}^{+}$donors and HTLV-I ${ }^{+}$ $\mathrm{T}$ cell lines express additional cell surface markers including the $\mathrm{T}$ cell activation markers (CD40, CD80, and CD86), TNF/TNFR family members (GITR, 4-1BB, 4-1BBL, OX40, and OX40L), the chemokine receptors/ interleukin receptors (CCR7 and CCR8), and a number of cell adhesion molecules, such as CD58/LFA3, CD54/ ICAM-1, and VCAM-1. Some of those molecules are induced by Tax1 [36], and the present study adds CD83 to the list of members of the HTLV-I and -II Tax-inducible protein family.

Tax1 is a transcriptional modulator that lacks the ability to directly bind to DNA elements; rather, it modifies cellular transcription factor activity, in particular via

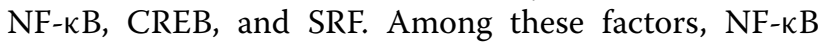
attenuated by Tax1 is critically involved in immortalization and transformation. The present study demonstrates that Tax1-mediated induction of CD83 is absolutely dependent on the NF- $\mathrm{KB}$ pathway, similar to that reported for OX40 [34] and OX40L [36]. It has been reported that the Epstein-Barr virus latent membrane protein 1 (LMP1), which is known to activate the NF- $\mathrm{kB}$ pathway, also induces CD83 expression in human B lymphocytes, in which an NF- $\mathrm{BB}$ binding site in the CD83 promoter is responsive for LMP1-mediated activation [37]. Our present study revealed that another NF- $\kappa B$ binding site in the $\mathrm{CD} 83$ promoter was responsive to 


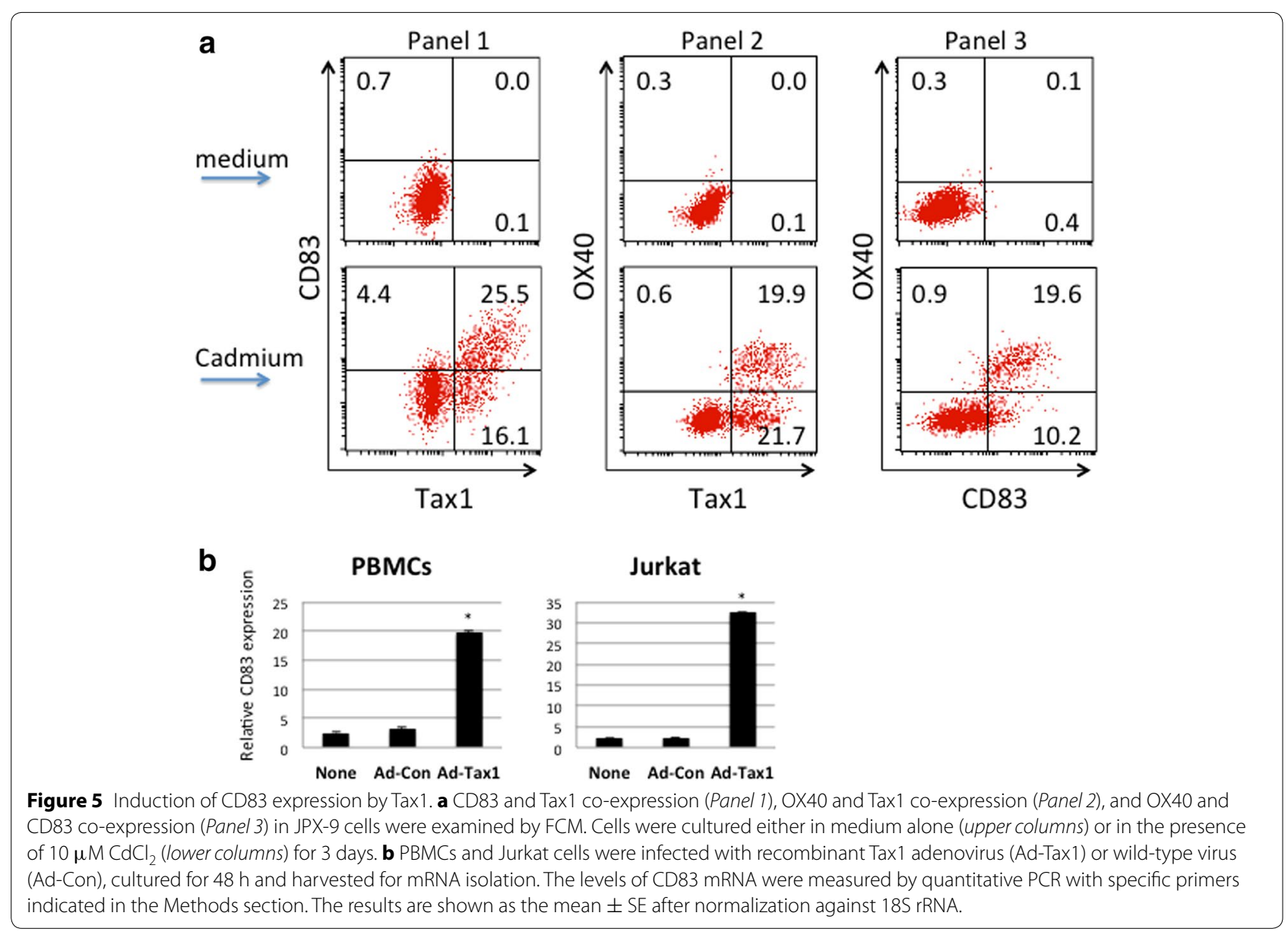

NF- $\kappa \mathrm{B}$ activated by Tax 1 in human $\mathrm{T}$ cells. It is of interest that the activation of NF- $\kappa B$ is insufficient for CD83 induction since a TL-Om1 cell line that contains a single copy of the HTLV-I provirus, but does not express Tax1, was negative for CD83 expression (Figure 2), while NF- $\mathrm{KB}$ in TL-Om1 is constitutively activated [38]. Thus, Tax1 expression may determine the promoter binding specificity and/or transcriptional regulation of NF- $\mathrm{KB}$ target genes such as CD83, OX40, and OX40L. Further studies are required to clarify the additional requirements for CD83 induction by Tax1.

The potential for CD83 induction by Tax1 in HTLV-I infections that leads to leukemogenesis or the onset of a neurological disorder, remains unknown. So far, CD83 modulation has been linked to virus escape from the $\mathrm{T}$ cell immune system. For example, human cytomegalovirus (HCMV) infection of DCs has been shown to inhibit $\mathrm{T}$ cell stimulation via release of sCD83 [39], and human herpes simplex virus (HSV) infection of mature DCs has been shown to downregulate the cell surface expression of CD83 by degradation of CD83 via the cellular proteasome [40]. Because the expression of either Tax1 or
CD83 on $\mathrm{CD}^{+} \mathrm{T}$ cells is difficult to detect and monitor in the peripheral blood, even in acute ATL patients (Figure 1), Tax1-induced CD83 seems to be indirectly associated with the onset of ATL or HAM/TSP. However, observations of the steady presence of strong CTL and high levels of antibody responses specific for HTLVI antigens in $\mathrm{HTLV}_{-}{ }^{+}$-infected individuals indicate the persistent production of HTLV-I in vivo. In addition, an immunodeficiency was found in ATL patients or healthy carriers [27-31], and the inability of monocytes from HTLV-I ${ }^{+}$donors to differentiate into mature DCs has been reported [32]. Integration of these results may provide some clues regarding the roles of CD83 in HTLV-I infection. First, Bates et al. recently reported that the homotypic interaction of mCD83 via cell-to-cell contact inhibits pro-inflammatory responses (including IL-12 production) induced by DCs [41]; accordingly, mCD83 induced on HTLV-I ${ }^{+} \mathrm{CD}^{+}{ }^{+} \mathrm{T}$ cells may interact with $\mathrm{mCD} 83$ on immuno-stimulated DCs in vivo and suppress IL-12 production, presumably resulting in inhibition of anti-HTLV-I Th1 responses. Second, sCD83 released from $\mathrm{Tax}^{+} \mathrm{CD} 4^{+} \mathrm{T}$ cells may interact with monocytes 


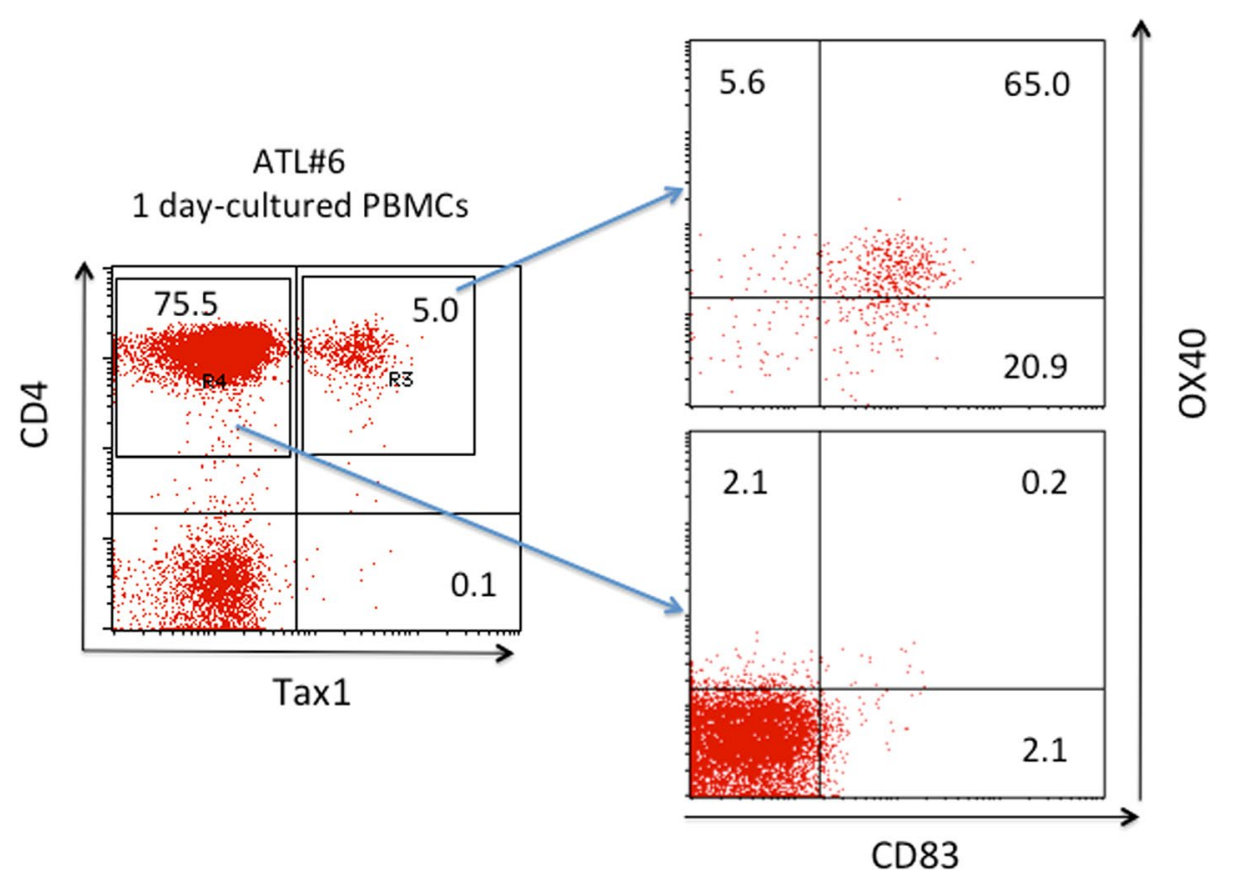

Figure 6 Co-expression of CD83 and OX40 on Tax $1^{+}$T cells. PBMCs of an ATL patient (\#6) were cultured for $18 \mathrm{~h}$ and stained with antibodies against CD4, Tax1, CD83 and OX40. CD4 ${ }^{+}$Tax $1^{-}$cells and CD4 ${ }^{+} \operatorname{Tax}^{+}{ }^{+}$T cells were gated and examined for their expression of CD83 and OX40 by FCM.

and stimulate the production of the pleotropic bioregulator PEG2. PEG2 has been reported to enhance HTLVI gag p19 production from PBMC cultures of HTLV-I carriers [42] and to stimulate HTLV-I LTR in combination with $\mathrm{CD} 3 / \mathrm{CD} 28$ activation in human $\mathrm{T}$ cell lines [43]. Consistent with these observations, we showed in the present study that PGE2 alone enhanced the expression of HTLV-I Tax1 and HTLV-I-mediated cell fusion (Figure 10). Therefore, it can be speculated that sCD83induced PGE2 from monocytes stimulates HTLV-I production and the expansion of HTLV-I ${ }^{+} \mathrm{CD}^{+}{ }^{+} \mathrm{T}$ cells via the induction of Tax1 expression in a paracrine manner. However, our preliminary experiments failed to show that soluble recombinant CD83 actually enhances HTLVI infection in vitro via production of PGE2 from primary monocytes. Further studies to test our hypotheses, including the link between T-cell activation by mCD83 and enhanced HTLV-I infection, are in progress.

Since normal human $\mathrm{T}$ cells express low to undetectable levels of CD83, high expression of both CD83 and OX40 on a single $\mathrm{CD} 4^{+} \mathrm{T}$ cell is a good marker of intracellular Tax1 expression. The sorting method for cells directly stained with anti-Tax antibody does not enable enrichment for live $\operatorname{Tax}^{+}$cells due to the required fixation and permeabilization of cells [44]. Thus, the present findings could provide a useful method for the enrichment of live $\operatorname{Tax}^{+} \mathrm{T}$ cells, as shown in Figure 7, and presumably will contribute to further studies on Tax1 function in the development and maintenance of HTLVI-related diseases.

\section{Conclusions}

The present study documents the potential role of HTLVI Tax in the induction of CD83 cell surface expression and release of sCD83 in an NF- $\mathrm{kB}$-dependent manner in human $\mathrm{CD}^{+} \mathrm{T}$ cells in vitro, which may indirectly suppress immune responses and promote HTLV-I infection in vivo in terms of virus transmission to new target cells and expansion and/or survival of infected $\mathrm{T}$ cell clones.

\section{Methods \\ Reagents}

The medium used throughout was RPMI 1640 medium (Sigma-Aldrich. Inc., St. Louis, MO, USA) supplemented with $10 \%$ fetal calf serum (FCS), $100 \mathrm{U} / \mathrm{ml}$ penicillin and $100 \mu \mathrm{g} / \mathrm{ml}$ streptomycin (hereinafter called RPMI medium). Mouse monoclonal antibodies (mAbs) specific for HTLV-I Tax (clone Lt-4), OX40 (clone B-7B5), and KLH (IgG3, clone KLH-3, Tanaka et al., unpublished) were purified in our laboratory from ascites fluids of CB.17-SCID mice carrying the appropriate hybridomas. The ascites fluid samples were subjected to ammonium sulfate precipitation followed by gel filtration with Superdex G-200 (GE Healthcare, Tokyo, Japan). mAbs were 

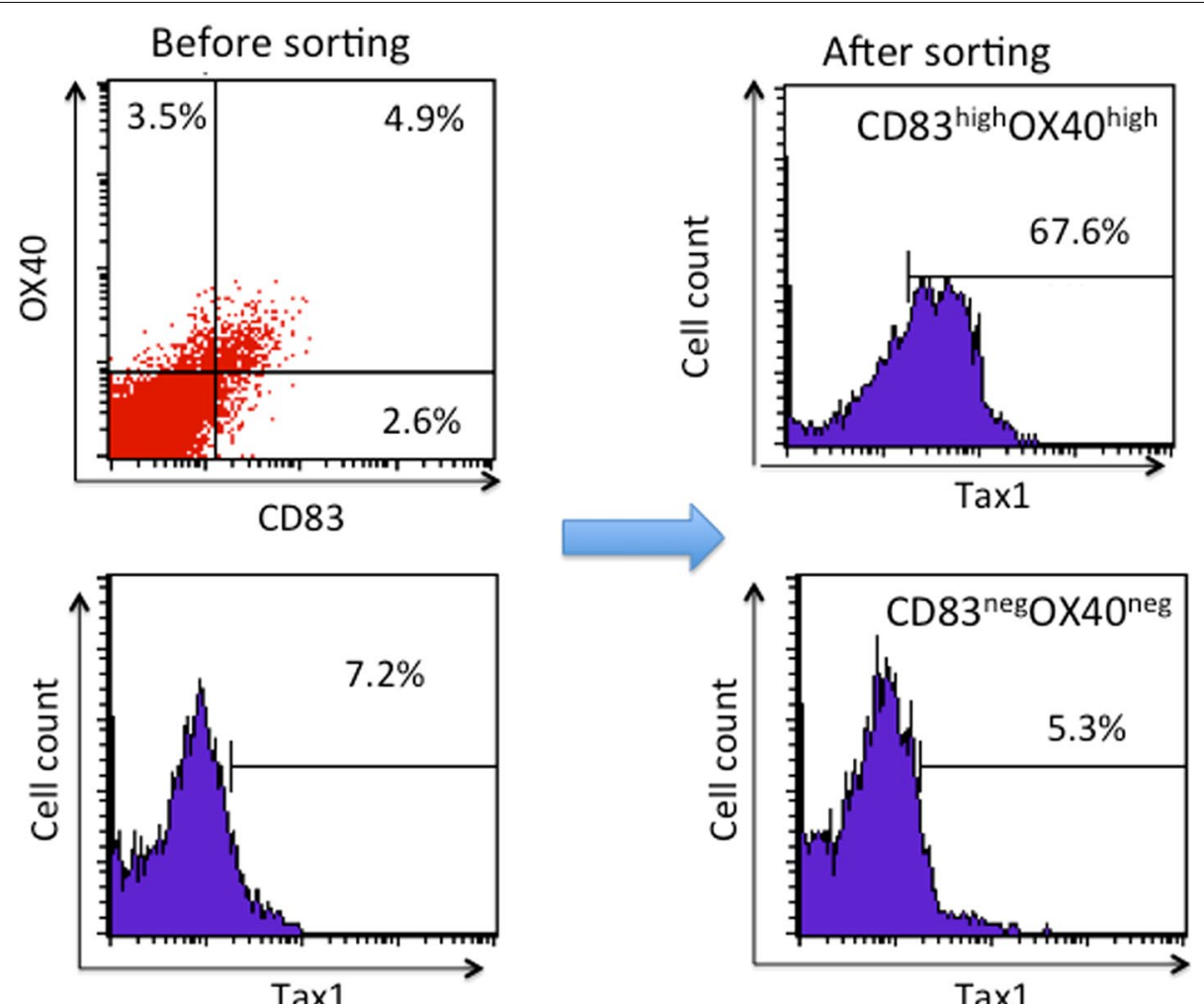

Figure 7 Flow cytometric analysis of Tax 1 expression of cell sorter purified CD83 $3^{\text {hi }} / \mathrm{OX} 40^{\text {hi }}$ and $\mathrm{CD} 83^{\text {negative }} / \mathrm{OX} 40^{\text {negative }}$ populations. An IL-2 dependent HTLV-I ${ }^{+}$T cell line generated from a HAM/TSP patient (OKH4) was stained with anti-OX40 and anti-CD83 mAbs. The CD83 ${ }^{+} \mathrm{OX} 40^{+}$and $\mathrm{CD}_{83}{ }^{-} \mathrm{OX} 40^{-}$populations were sorted, and stained for Tax1. The Tax1 expression profiles prior to and post sorting are shown.

labeled with either fluorescein isothiocyanate (FITC) or HiLyte Fluor ${ }^{\mathrm{m}} 647$ using commercial labeling kits (Dojindo, Kumamoto, Japan) according to the manufacturer's instructions. FITC-, PE- or PE-Cy7-labeled mouse mAbs against human CD3, CD4, CD8, CD14, CD19, CD56, and CD83 (clone H15e), and FITC-labeled goat anti-rat IgG, donkey anti-rabbit IgG, and HRP-labeled goat anti-rat IgG antibodies were purchased from BioLegend (Tokyo, Japan). Rabbit polyclonal IgG anti-rat CD83 antibody was obtained from Sino Biological (Beijing, China). Prostaglandin E2 (PGE2) was purchased from Sigma-Aldrich. Inc., (St. Louis, MO, USA).

\section{Cell cultures}

The protocols for the use of human PBMCs and animals were approved by the Human IRB and the Institutional Animal Care and Use Committee (IACUC) on clinical and animal research of the University of the Ryukyus and Tokyo Medical and Dental University prior to the initiation of the study. All human samples were collected after obtaining written informed consent according to the Declaration of Helsinki. PBMCs were isolated from heparinized blood by a standard density gradient centrifugation [26]. HTLV-I-producing $\mathrm{T}$ cell lines were IL-2-independent $\mathrm{T}$ cell lines (MT-1, MT-2, and HUT102), IL-2-dependent $\mathrm{CD} 4^{+}$and $\mathrm{CD}^{+}{ }^{+} \mathrm{T}$ cell lines derived from various $\mathrm{HTLV}^{+} \mathrm{I}^{+}$donors (ATL patients, HAM/TSP patients, or asymptomatic HTLV-I carriers), and $\mathrm{CD}^{+} \mathrm{T}$ cell lines derived from normal PBMCs established by co-cultivation with mitomycin $\mathrm{C}$-treated HTLV-I-producing cells [26]. The TL-Om1 cell line is an ATL-patient-derived IL-2-independent HTLV-I-infected $\mathrm{T}$ cell line not expressing the Tax antigen [38]. The $\mathrm{HTLV}^{+} \mathrm{I}^{+}$rat T cell line was W7TM-1 [45]. The HTLVI-negative human T cell lines were Jurkat, CEM, Molt-4, Molt-4/IIIB, and Jurkat-derived JPX-9, in which Tax1 can be induced by cultivation in the presence of $10 \mu \mathrm{M} \mathrm{CdCl}_{2}$ [46]. The HTLV-II ${ }^{+}$human $\mathrm{T}$ cell line was Ton1 [47]. Cell lines were cultured in RPMI medium in the presence of $20 \mathrm{U} / \mathrm{ml}$ recombinant human IL-2, if necessary. For select experiments, human PBMCs were stimulated with $10 \mu \mathrm{g} / \mathrm{ml}$ phytohemagglutinin (PHA) (Wako, Japan) or immobilized anti-CD3 and anti-CD28 mAbs (BioLegend). Derivatives of 293T cells expressing human CD83 (293T/CD83) and its vector control (293T/CT) were established in our laboratory by transfection of 293T 
a

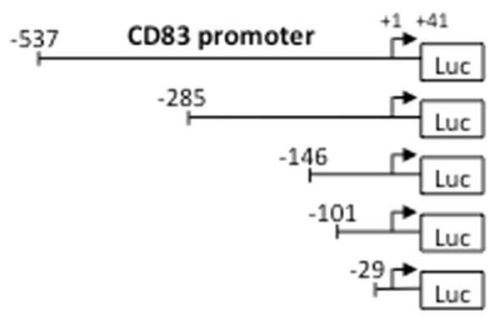

pCD83(-537)Luc

pCD83(-285)Luc

pCD83(-146)Luc

pCD83(-101)Luc

pCD83(-29)Luc

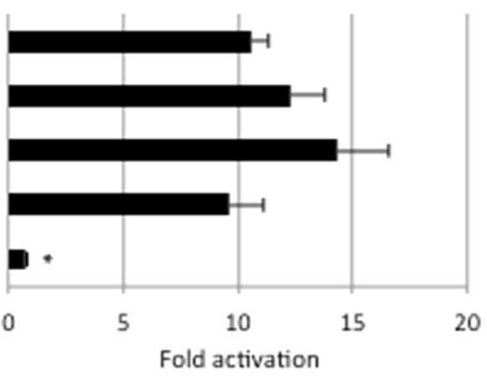

b

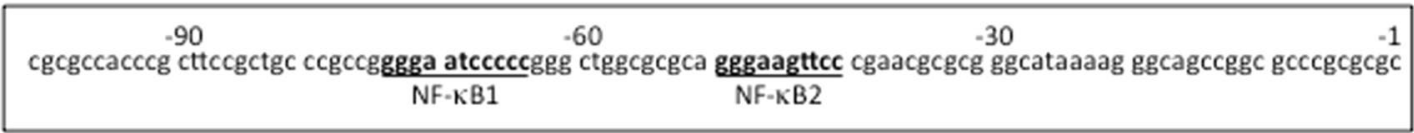

c

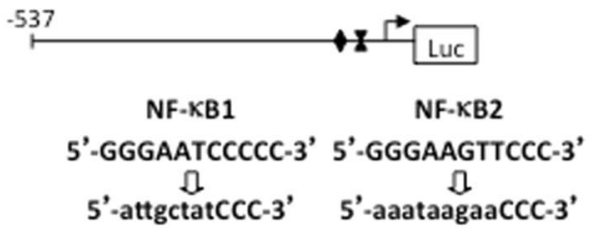

d

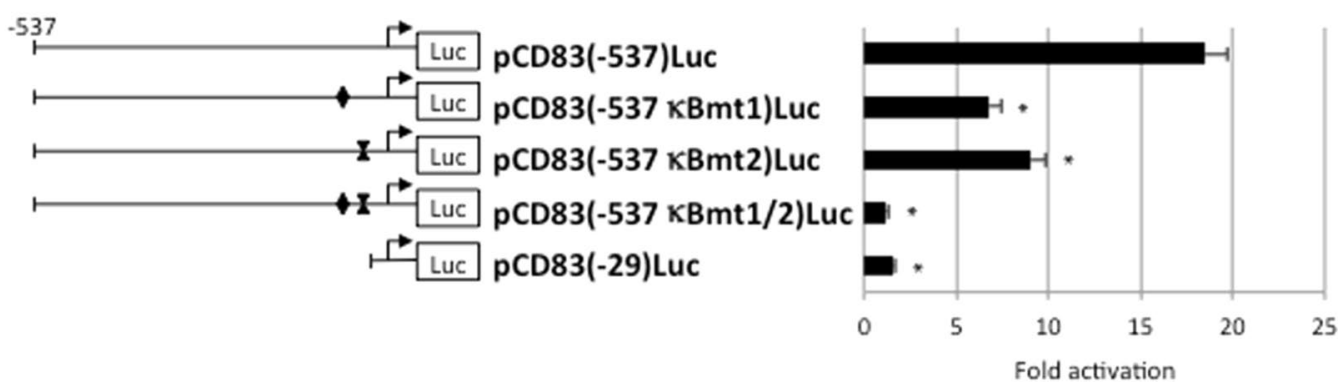

Figure 8 Tax1-responsive elements in the CD83 promoter. a Luciferase reporter plasmids carrying the wild-type $(-537$ to +41$)$ and its $5^{\prime}$ deletion mutants ( -285 to $+41,-146$ to $+41,-101$ to +41 , and -29 to +41 ) of the CD83 promoter were transfected into Jurkat cells along with the Tax 1 expression plasmid (pMT-2Tax). Cells were cultured for $48 \mathrm{~h}$ and analyzed for luciferase activity. The results were normalized based on protein content. b Nucleotide sequences of the CD83 promoter ( -101 to -1 with respect to the transcription start site). Possible NF-kB binding sites (NF-

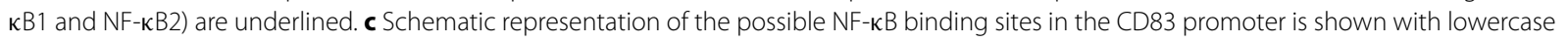
letters indicating mutated sequences. d Reporter plasmids carrying the wild-type CD83 promoter or mutant promoter were transfected into Jurkat cells along with the Tax 1 expression plasmid (pMT-2Tax). Cells were cultured for $48 \mathrm{~h}$ and analyzed for luciferase assay. The results shown are as the mean $\pm \mathrm{SE}$ after normalization based on protein content.

cells with human CD83 vector (pCAGIPuro/CD83) and empty vector (pCAGIPuro), respectively.

Syncytium induction assay was performed using a combination of ILT-M1 and Jurkat cells as described previously [26].

\section{Generation of a new anti-CD83 mAb}

Hybridomas producing mAbs against human CD83 were generated from spleen cells of WKA rats immunized with recombinant human CD83-Fc fusion protein (R\&D Systems, Inc., Cosmo Bio, Tokyo, Japan) by cell fusion with the SP2/0 myeloma cell line utilizing the Sendai virus cell fusion kit (GenomeONE, Cosmo Bio), and screened by ELISA using CD83-Fc-coated plates $(0.1 \mu \mathrm{g} / \mathrm{ml}$ per well) and goat anti-rat IgG-HRP antibody (BioLegend). mAbs were further selected based on their abilities to stain CD83 expressed on 293T/CD83 cells but not 293T/ $\mathrm{CT}$ cells. Western blots were performed as reported previously [48]. The anti-CD $83 \mathrm{mAbs}$ established by this screening included clones W83\#4 and W83\#8, both of which were rat IgG2b and applicable for flow cytometry. The clone W83\#4, but not W83\#8, competed in a binding assay with a commercially available mouse anti-human CD83 mAb clone H15e. The clone W83\#8, but not W83\#4 or H15e, was applicable for western blot analysis (data not shown). 


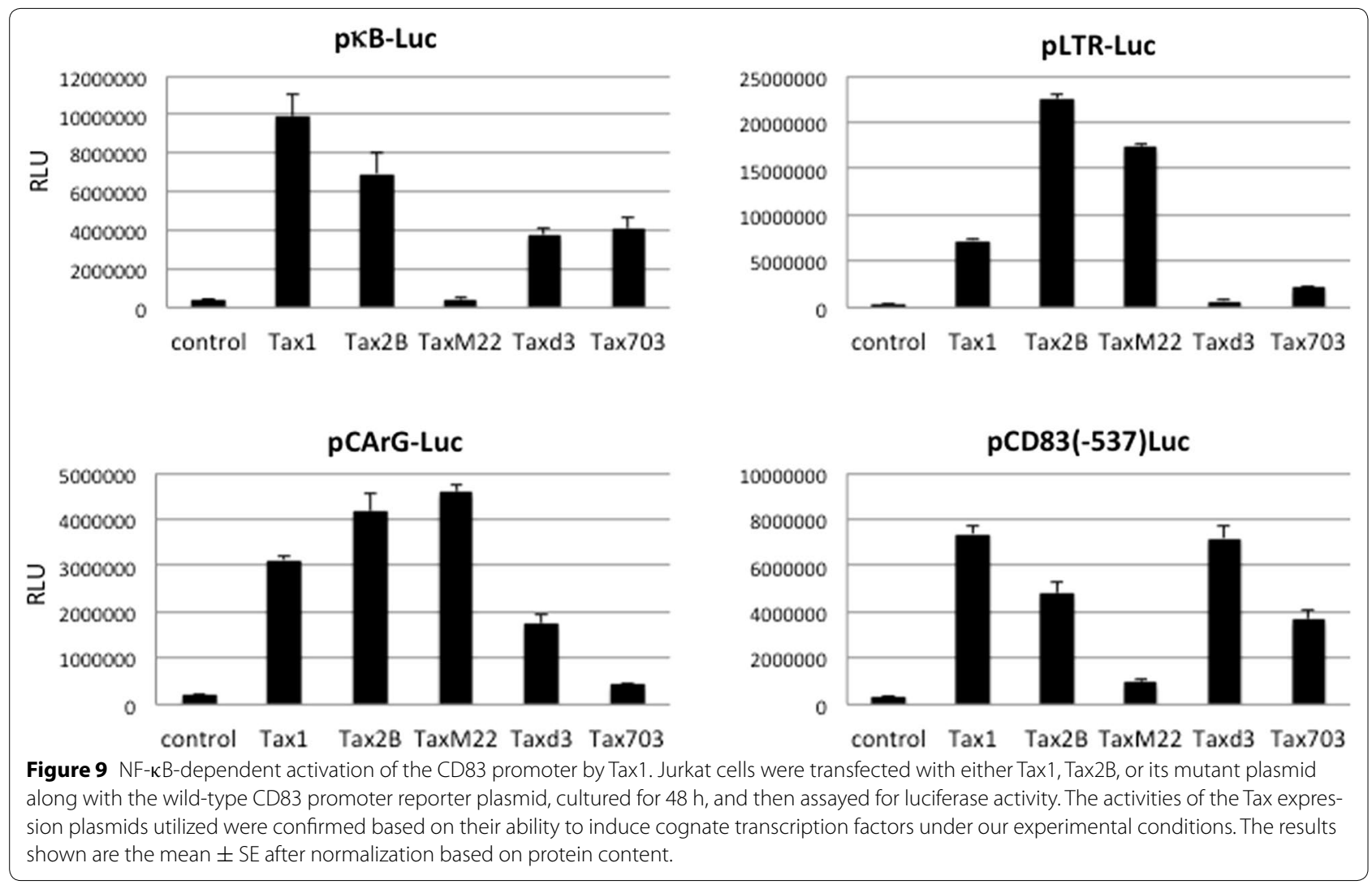

\section{Flow cytometry (FCM), cell sorting, and ELISA}

Phenotypic analyses of cells were carried out using polychromatic flow cytometry (FCM) as reported previously [26]. Briefly, live cells were Fc-blocked with $2 \mathrm{mg} / \mathrm{ml}$ pooled normal human IgG in FACS buffer [PBS containing $0.2 \%$ bovine serum albumin (BSA) and $0.1 \%$ sodium azide] for 10 min on ice, followed by incubation with fluorescent-dye labeled mAbs for $30 \mathrm{~min}$. After washing with FACS buffer, the cells were fixed in $4 \%$ paraformaldehyde (PFA) in PBS for $5 \mathrm{~min}$ at room temperature followed by permeabilization and washing in FACS buffer containing $0.5 \%$ saponin and $1 \%$ BSA (Sigma). An aliquot of the stained cells was incubated with $0.1 \mu \mathrm{g} / \mathrm{ml}$ HiLyte Fluor ${ }^{\mathrm{rm}}$ 647-labeled anti-Tax1 antibody (clone Lt-4) for $30 \mathrm{~min}$. Negative control cells were stained with HiLyte Fluor ${ }^{\mathrm{Tm}} 647$-labeled Lt- 4 in the presence of $100 \mu \mathrm{g} / \mathrm{ml}$ unlabeled Lt-4. These cells were analyzed using a FACSCalibur (BD, Franklin Lakes, N), USA) and data obtained were analyzed using the Cell Quest software (BD).

To sort CD83 and OX40 double-positive and doublenegative cell populations, IL-2-dependent $\mathrm{T}$ cell lines established from $\mathrm{HTLV}_{-}{ }^{+}$donors were stained with PE-Cy7-labeled anti-CD83 (clone H15e) and PE-labeled
anti-OX40 (clone B-7B5) mAbs, and then subjected to sorting using a cell sorter SH800Z (Sony, Tokyo, Japan) equipped with appropriate filters for multi-color analysis in a dual semiconductor laser $(488) /(639 \mathrm{~nm})$ system.

sCD83 in culture supernatants and cell lysates were quantitated using a commercial ELISA kit (MyBiosource, San Diego, CA, USA). HTLV-I p24 production into the culture supernatants was determined by our in-house formulated ELISA [26].

\section{Plasmids}

Expression plasmids for Tax1 (pMT-2Tax), Tax2B (pH $\beta$ AP-r1-neo Tax2B), and Tax1 mutants were derived using the pHßAP-r-1-neo system with the human $\beta$-actin promoter $[49,50]$. Tax1 mutants lacking the ability to activate NF-кB (TaxM22), CREB (Taxd3), and SRF (Tax703) in $\mathrm{T}$ cells have been described previously [50]. The luciferase reporter plasmids for the NF- $\kappa B$ site (pкB-Luc), CREB binding site (pLTR-Luc), and CArG box (pCArG-Luc) have been described elsewhere [51-53]. The CD83 reporter plasmid [pCD83(-537)Luc] was generated by insertion of a 578-bp fragment $(-537$ to +41 from the transcription start site [54]) amplified from human genomic DNA by PCR using forward 

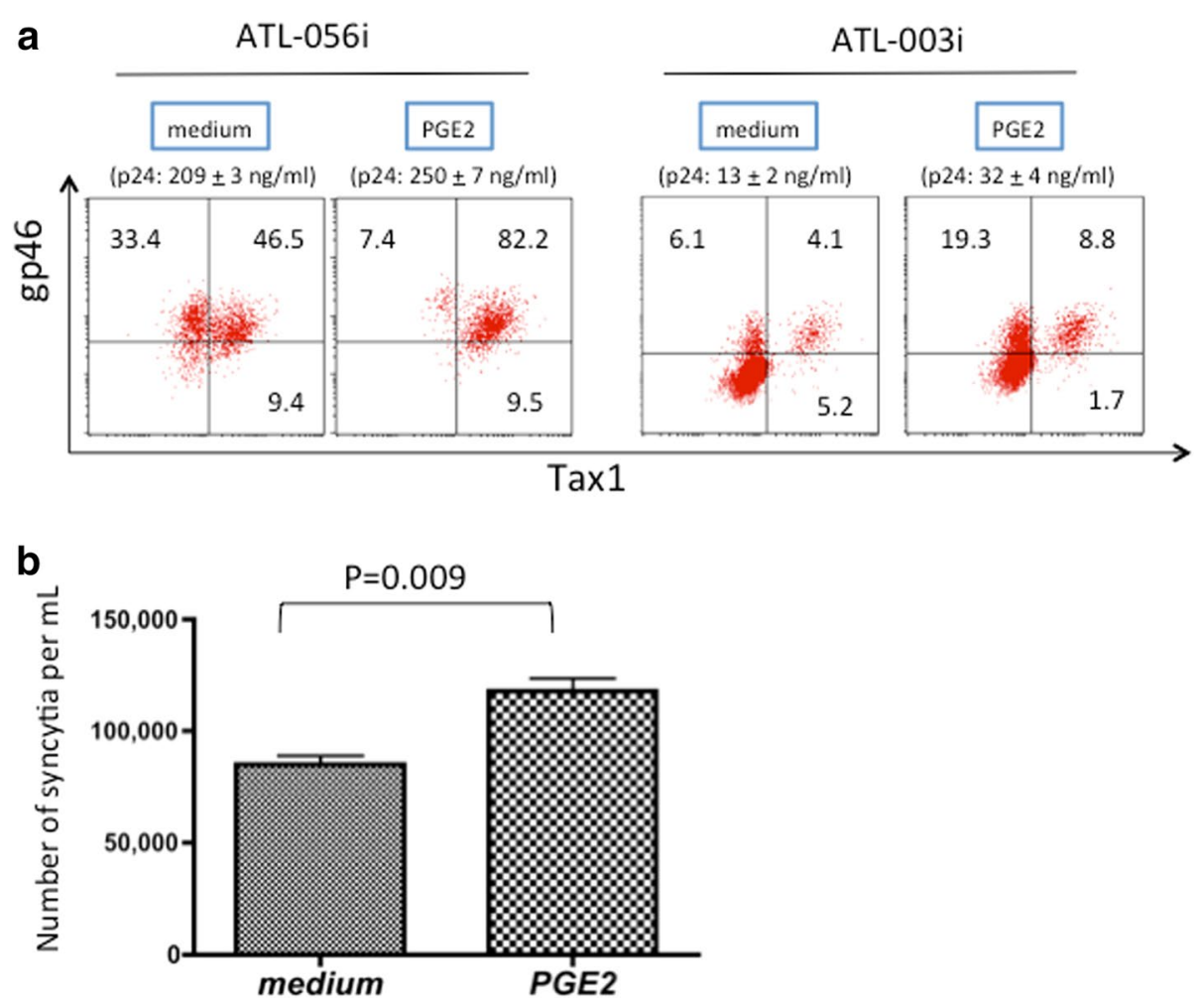

Figure 10 Enhancement of Tax1 expression and HTLV-I infectivity by prostaglandin E2 (PGE2). a ATL-patient-derived IL-2-dependent CD4 ${ }^{+} \mathrm{T}$ cell lines (ATL-056i and ATL-003i) were cultured in the presence or absence of $100 \mathrm{ng} / \mathrm{ml} \mathrm{PGE2} \mathrm{for} 24 \mathrm{~h}$ and examined for the expression of Tax 1 and HTLV-I envelope gp46 antigen by FCM. The levels of HTLV-I gag p24 released into the culture supernatants were determined by ELISA and are shown on the top of the dot plot. b ATL-056i cells suspended at $1 \times 10^{6} \mathrm{cell} / \mathrm{s} / \mathrm{ml}$ either untreated or treated with PGE2 for $24 \mathrm{~h}$ were co-cultured with an equal volume of Jurkat cells $\left(1 \times 10^{6} \mathrm{cell} / \mathrm{s} / \mathrm{ml}\right)$ for an additional $18 \mathrm{~h}$ in triplicate wells. Then, the numbers of syncytia (per $\left.\mathrm{ml}\right)$ were counted manually as described previously [26].

(5'-acgctagccatggaaatctaacgcgccttt-3') and reverse (5'-gtaa gcttggctggagcgctgcgccgctgc-3') primer pairs. The insert was cloned into the NheI and HindIII sites of the pGL3basic vector. A series of $5^{\prime}$ deletion mutants of the human CD83 promoter was generated by PCR and inserted into pGL3-basic, yielding pCD83(-285)Luc, pCD83(-146)Luc, pCD83(-101)Luc, and pCD83(-29)Luc. The substitution mutants of the two possible NF- $\mathrm{kB}$ binding sites in the CD83 promoter were generated by PCR using the mutant primers, yielding pCD83(-537 кBmt1)Luc, pCD83(-537 $\kappa B m t 2) L u c$, and pCD83(-537 $\kappa$ Bmt1/2)Luc with muta-

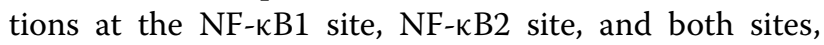
respectively (see Figure 8c, d).

\section{Infection with adenoviruses}

Recombinant adenovirus for Tax1 (Ad-Tax1) [55] was generated with the ViraPower adenoviral expression system with the CAG promoter according to the supplier's instructions. PBMCs and Jurkat cells were infected at an MOI of 100 or 10 plaque forming units (PFU)/cell, respectively, as previously described $[56,57]$.

\section{Quantitative PCR}

Total RNA was extracted using Isogen (Nippon Gene Co. Ltd., Tokyo, Japan) according to the supplier's protocol. First-strand cDNA was synthesized using the firststrand cDNA synthesis kit for reverse transcription-PCR (AMV; Roche, Tokyo, Japan). Quantification of CD83 gene expression was performed utilizing the forward $\left(5^{\prime}\right.$-gcgacgccggaggtgaaggtg- $\left.3^{\prime}\right)$ and reverse $\left(5^{\prime}\right.$-tccccgagttgcagctggtagtgt- $3^{\prime}$ ) primer pair using a LightCycler (Roche). The 18S rRNA primers were obtained from TaKaRa (Shiga, Japan).

\section{Reporter assay}

Jurkat cells were transfected with Tax expression plasmids along with reporter plasmids by the DEAE-dextran method described previously [58]. Cell lysates were prepared for determination of luciferase activity using the luciferase assay system (Promega, Tokyo, Japan) according to the manufacture's recommendations. Normalization of luciferase activity was performed against the cell lysate protein concentration that was measured by the DC Protein Assay 
Kit (Bio-Rad, Tokyo, Japan). The assays were repeated at least three times and the mean \pm SE values are shown.

\section{Statistical analysis}

A paired $t$-test was performed for statistical analysis. P-values of less than 0.05 were considered significant.

\section{Additional file}

Additional file 1: Figure S1. Western blot analysis of Tax1 expression in PBMCs from an ATL patient (ATL \#5) before or after a one-day culture. Cell lysates were subjected to SDS-PAGE on a $5-20 \%$ gel, and blotted onto PVDF membranes. The membranes were incubated with either mouse anti-human Tax 1 mAb (clone Lt-4) or lgG3 isotype control mAb (anti-KLH), followed by treatment with HRP-labeled goat anti-mouse lgG antibody.

\section{Abbreviations}

HTLV-I: human T-cell leukemia virus type-l; Tax1: a transactivator from the X-gene region of HTLV-I; ATL: adult T-cell leukemia; FCM: flow cytometry; PBMCs: peripheral blood mononuclear cells; PHA: phytohemagglutinin; SDSPAGE: SDS-polyacrylamide gel electrophoresis; MW: molecular weight; KLH: Keyhole limpet hemocyanin.

\section{Authors' contributions}

YTan conceived of the study, participated in its design and coordination, carried out the FCM assays, and drafted the manuscript. MM and MN carried out molecular studies, YTak established the CD83-expressing cell line and ATL T cell lines, HF carried out the cell sorting, RT produced, purified, and labeled mAbs, confirmed their specificities, and made in-house EILSA kits, TF and TT collected blood samples from HTLV-I ${ }^{+}$patients, and AAA participated in the design of the study and helped to draft the manuscript. All authors read and approved the final manuscript.

\section{Author details}

1 Department of Immunology, Graduate School of Medicine, University of the Ryukyus, 207 Uehara, Nishihara-cho, Okinawa 903-0215, Japan. ${ }^{2}$ Human Gene Sciences Center, Tokyo Medical and Dental University, 1-5-45 Yushima, Bunkyo-ku, Tokyo, Japan. ${ }^{3}$ Laboratory of Hematoimmunology, School of Health Sciences, Faculty of Medicine, University of the Ryukyus, Okinawa, Japan. ${ }^{4}$ Division of Endocrinology, Diabetes and Metabolism, Haematology, Rheumatology (Second Department of Internal Medicine), Graduate School of Medicine, University of the Ryukyus, Okinawa, Japan. ${ }^{5}$ Department of Pathology, Emory University School of Medicine, Atlanta, GA, USA.

\section{Acknowledgements}

We thank Prof. M. Fujii at Niigata University for providing Ton 1 cells. This work was supported by grants from the Ministry of Education, Culture, Sports, Science, and Technology and the Ministry of Health, Labor, and Welfare of Japan, and Okinawa prefecture.

\section{Compliance with ethical guidelines}

\section{Competing interests}

The authors declare that they have no competing interests.

Received: 23 April 2015 Accepted: 21 June 2015

Published online: 01 July 2015

\section{References}

1. Zhou LJ, Schwarting R, Smith HM, Tedder TF (1992) A novel cell-surface molecule expressed by human interdigitating reticulum cells, Langerhans cells, and activated lymphocytes is a new member of the Ig superfamily. J Immunol 149:735-742
2. Cao W, Lee SH, Lu J (2005) CD83 is preformed inside monocytes, macrophages and dendritic cells, but it is only stably expressed on activated dendritic cells. Biochem J 385:85-93

3. Wolenski M, Cramer SO, Ehrlich S, Steeg C, Grossschupff G, Tenner-Racz $K$ et al (2003) Expression of CD83 in the murine immune system. Med Microbiol Immunol 192:189-192

4. Prazma CM, Yazawa N, Fujimoto Y, Fujimoto M, Tedder TF (2007) CD83 expression is a sensitive marker of activation required for B cell and CD4+ T cell longevity in vivo. J Immunol 179:4550-4562

5. Reinwald S, Wiethe C, Westendorf AM, Breloer M, Probst-Kepper M, Fleischer B et al (2008) CD83 expression in CD4+ T cells modulates inflammation and autoimmunity. J Immunol 180:5890-5897

6. Yamashiro S, Wang JM, Yang D, Gong WH, Kamohara H, Yoshimura T (2000) Expression of CCR6 and CD83 by cytokine-activated human neutrophils. Blood 96:3958-3963

7. Mailliard RB, Alber SM, Shen H, Watkins SC, Kirkwood JM, Herberman RB et al (2005) IL-18-induced CD83+ CCR7+ NK helper cells. J Exp Med 202:941-953

8. Fujimoto Y, Tu L, Miller AS, Bock C, Fujimoto M, Doyle C et al (2002) CD83 expression influences CD4+T cell development in the thymus. Cell 108:755-767

9. Hock BD, Kato M, McKenzie JL, Hart DN (2001) A soluble form of CD83 is released from activated dendritic cells and B lymphocytes, and is detectable in normal human sera. Int Immunol 13:959-967

10. Aerts-Toegaert C, Heirman C, Tuyaerts S, Corthals J, Aerts JL, Bonehill A et al (2007) CD83 expression on dendritic cells and T cells: correlation with effective immune responses. Eur J Immunol 37:686-695

11. Lechmann M, Krooshoop DJ, Dudziak D, Kremmer E, Kuhnt C, Figdor CG et al (2001) The extracellular domain of CD83 inhibits dendritic cellmediated T cell stimulation and binds to a ligand on dendritic cells. J Exp Med 194:1813-1821

12. Lin H, Liang S, Zhong Z, Wen J, Li W, Wang L et al (2014) Soluble CD83 inhibits human monocyte differentiation into dendritic cells in vitro. Cell Immunol 292:25-31

13. Hock BD, Fernyhough $L$, Gough SM, Steinkasserer A, Cox AG, McKenzie $J L$ (2009) Release and clinical significance of soluble CD83 in chronic lymphocytic leukemia. Leuk Res 33:1089-1095

14. Kreiser S, Eckhardt J, Kuhnt C, Stein M, Krzyzak L, Seitz C et al (2015) Murine CD83-positive T cells mediate suppressor functions in vitro and in vivo. Immunobiology 220:270-279

15. Chen L, Zhu Y, Zhang G, Gao C, Zhong W, Zhang X (2011) CD83-stimulated monocytes suppress T-cell immune responses through production of prostaglandin E2. Proc Natl Acad Sci USA 108:18778-18783

16. Hinuma Y, Nagata K, Hanaoka M, Nakai M, Matsumoto T, Kinoshita KI (1981) Adult T-cell leukemia: antigen in an ATL cell line and detection of antibodies to the antigen in human sera. Proc Natl Acad Sci USA 78:6476-6480

17. Gessain A, Barin F, Vernant JC, Gout O, Maurs L, Calender A et al (1985) Antibodies to human T-lymphotropic virus type-l in patients with tropical spastic paraparesis. Lancet 2:407-410

18. Osame M, Matsumoto M, Usuku K, Izumo S, ljichi N, Amitani H et al (1987) Chronic progressive myelopathy associated with elevated antibodies to human T-lymphotropic virus type I and adult T-cell leukemialike cells. Ann Neurol 21:117-122

19. Ishitsuka K, Tamura K (2014) Human T-cell leukaemia virus type I and adult T-cell leukaemia-lymphoma. Lancet Oncol 15:e517-e526

20. Yoshida M (2010) Molecular approach to human leukemia: isolation and characterization of the first human retrovirus HTLV-1 and its impact on tumorigenesis in adult T-cell leukemia. Proc Jpn Acad Ser B Phys Biol Sci 86:117-130

21. Romanelli MG, Diani E, Bergamo E, Casoli C, Ciminale V, Bex F et al (2013) Highlights on distinctive structural and functional properties of HTLV TaX proteins. Front Microbiol 4:271

22. Matsuoka M, Yasunaga J (2013) Human T-cell leukemia virus type 1: replication, proliferation and propagation by Tax and HTLV-1 bZIP factor. Curr Opin Virol 3:684-691

23. Hinuma Y, Gotoh Y, Sugamura K, Nagata K, Goto T, Nakai M et al (1982) A retrovirus associated with human adult T-cell leukemia: in vitro activation. Gan 73:341-344 
24. Gotoh Yl, Sugamura K, Hinuma Y (1982) Healthy carriers of a human retrovirus, adult T-cell leukemia virus (ATLV): demonstration by clonal culture of ATLV-carrying T cells from peripheral blood. Proc Natl Acad Sci USA 79:4780-4782

25. Bangham CR (2009) CTL quality and the control of human retroviral infections. Eur J Immunol 39:1700-1712

26. Tanaka Y, Takahashi Y, Tanaka R, Kodama A, Fujii H, Hasegawa A et al (2014) Elimination of human T cell leukemia virus type-1-infected cells by neutralizing and antibody-dependent cellular cytotoxicity-inducing antibodies against human t cell leukemia virus type-1 envelope gp46. AIDS Res Hum Retroviruses 30:542-552

27. Murphy EL, Glynn SA, Fridey J, Smith JW, Sacher RA, Nass CC et al (1999) Increased incidence of infectious diseases during prospective follow-up of human T-lymphotropic virus type II- and I-infected blood donors. Retrovirus Epidemiology Donor Study. Arch Intern Med 159:1485-1491

28. Yamazato Y, Miyazato A, Kawakami K, Yara S, Kaneshima H, Saito A (2003) High expression of p40(tax) and pro-inflammatory cytokines and chemokines in the lungs of human T-lymphotropic virus type 1-related bronchopulmonary disorders. Chest 124:2283-2292

29. Santos SB, Porto AF, Muniz AL, de Jesus AR, Magalhaes E, Melo A et al (2004) Exacerbated inflammatory cellular immune response characteristics of HAM/TSP is observed in a large proportion of HTLV-I asymptomatic carriers. BMC Infect Dis 4:7

30. Funai N, Shimamoto Y, Yoshida S, Nagai Y, Nakazato S, Kohashi O (1996) Differences in immune functions between human T-lymphotropic virus type I carriers and patients with adult T-cell leukemia/lymphoma. Clin Immunol Immunopathol 80:325-332

31. Yasunaga J, Sakai T, Nosaka K, Etoh K, Tamiya S, Koga S et al (2001) Impaired production of naive T lymphocytes in human T-cell leukemia virus type l-infected individuals: its implications in the immunodeficient state. Blood 97:3177-3183

32. Nascimento CR, Lima MA, de Andrada Serpa MJ, Espindola O, Leite AC, Echevarria-Lima J (2011) Monocytes from HTLV-1-infected patients are unable to fully mature into dendritic cells. Blood 117:489-499

33. Hock BD, Haring LF, Steinkasserer A, Taylor KG, Patton WN, McKenzie JL (2004) The soluble form of CD83 is present at elevated levels in a number of hematological malignancies. Leuk Res 28:237-241

34. Higashimura N, Takasawa N, Tanaka Y, Nakamura M, Sugamura K (1996) Induction of OX40, a receptor of gp34, on T cells by trans-acting transcriptional activator, Tax, of human T-cell leukemia virus type I. Jpn J Cancer Res 87:227-231

35. Kress AK, Grassmann R, Fleckenstein B (2011) Cell surface markers in HTLV-1 pathogenesis. Viruses 3:1439-1459

36. Ohtani K, Tsujimoto A, Tsukahara T, Numata N, Miura S, Sugamura K et al (1998) Molecular mechanisms of promoter regulation of the gp34 gene that is trans-activated by an oncoprotein Tax of human T cell leukemia virus type I. J Biol Chem 273:14119-14129

37. Dudziak D, Kieser A, Dirmeier U, Nimmerjahn F, Berchtold S, Steinkasserer A et al (2003) Latent membrane protein 1 of Epstein-Barr virus induces CD83 by the NF-kappaB signaling pathway. J Virol 77:8290-8298

38. Mori N, Fujii M, Ikeda S, Yamada Y, Tomonaga M, Ballard DW et al (1999) Constitutive activation of NF-kappaB in primary adult T-cell leukemia cells. Blood 93:2360-2368

39. Senechal B, Boruchov AM, Reagan JL, Hart DN, Young JW (2004) Infection of mature monocyte-derived dendritic cells with human cytomegalovirus inhibits stimulation of T-cell proliferation via the release of soluble CD83. Blood 103:4207-4215

40. Kummer M, Turza NM, Muhl-Zurbes P, Lechmann M, Boutell C, Coffin RS et al (2007) Herpes simplex virus type 1 induces CD83 degradation in mature dendritic cells with immediate-early kinetics via the cellular proteasome. J Virol 81:6326-6338

41. Bates JM, Flanagan K, Mo L, Ota N, Ding J, Ho S et al (2015) Dendritic cell CD83 homotypic interactions regulate inflammation and promote mucosal homeostasis. Mucosal Immunol 8:414-428
42. Moriuchi M, Inoue H, Moriuchi H (2001) Reciprocal interactions between human T-lymphotropic virus type 1 and prostaglandins: implications for viral transmission. J Virol 75:192-198

43. Dumais N, Pare ME, Mercier S, Bounou S, Marriot SJ, Barbeau B et al (2003) T-cell receptor/CD28 engagement when combined with prostaglandin E2 treatment leads to potent activation of human T-cell leukemia virus type 1. J Virol 77:11170-11179

44. Melamed A, Laydon DJ, Gillet NA, Tanaka Y, Taylor GP, Bangham CR (2013) Genome-wide determinants of proviral targeting, clonal abundance and expression in natural HTLV-1 infection. PLoS Pathog 9:e1003271

45. Tanaka Y, Tozawa H, Koyanagi Y, Shida H (1990) Recognition of human T cell leukemia virus type I (HTLV-I) gag and pX gene products by MHCrestricted cytotoxic $T$ lymphocytes induced in rats against syngeneic HTLV-I-infected cells. J Immunol 144:4202-4211

46. Miura S, Ohtani K, Numata N, Niki M, Ohbo K, Ina Y et al (1991) Molecular cloning and characterization of a novel glycoprotein, gp34, that is specifically induced by the human T-cell leukemia virus type I transactivator p40tax. Mol Cell Biol 11:1313-1325

47. Ootsuyama Y, Shimotohno K, Miwa M, Oroszlan S, Sugimura T (1985) Myristylation of gag protein in human T-cell leukemia virus type-I and type-II. Jpn J Cancer Res 76:1132-1135

48. Tanaka R, Yoshida A, Murakami T, Baba E, Lichtenfeld J, Omori T et al (2001) Unique monoclonal antibody recognizing the third extracellular loop of CXCR4 induces lymphocyte agglutination and enhances human immunodeficiency virus type 1-mediated syncytium formation and productive infection. J Virol 75:11534-11543

49. Gunning P, Leavitt J, Muscat G, Ng SY, Kedes L (1987) A human beta-actin expression vector system directs high-level accumulation of antisense transcripts. Proc Natl Acad Sci USA 84:4831-4835

50. Matsumoto K, Shibata H, Fujisawa JI, Inoue H, Hakura A, Tsukahara T et al (1997) Human T-cell leukemia virus type 1 Tax protein transforms rat fibroblasts via two distinct pathways. J Virol 71:4445-4451

51. Akagi T, Ono H, Nyunoya H, Shimotohno K (1997) Characterization of peripheral blood T-lymphocytes transduced with HTLV-I Tax mutants with different trans-activating phenotypes. Oncogene 14:2071-2078

52. Hirai H, Suzuki T, Fujisawa J, Inoue J, Yoshida M (1994) Tax protein of human T-cell leukemia virus type I binds to the ankyrin motifs of inhibitory factor kappa B and induces nuclear translocation of transcription factor NF-kappa B proteins for transcriptional activation. Proc Natl Acad Sci USA 91:3584-3588

53. Fujisawa J, Toita M, Yoshida M (1989) A unique enhancer element for the trans activator (p40tax) of human T-cell leukemia virus type I that is distinct from cyclic AMP- and 12-O-tetradecanoylphorbol-13-acetateresponsive elements. J Virol 63:3234-3239

54. Kozlow EJ, Wilson GL, Fox CH, Kehrl JH (1993) Subtractive cDNA cloning of a novel member of the Ig gene superfamily expressed at high levels in activated B lymphocytes. Blood 81:454-461

55. Mizuguchi M, Asao H, Hara T, Higuchi M, Fujii M, Nakamura M (2009) Transcriptional activation of the interleukin-21 gene and its receptor gene by human T-cell leukemia virus type 1 Tax in human T-cells. J Biol Chem 284:25501-25511

56. Hirai H, Fujisawa J, Suzuki T, Ueda K, Muramatsu M, Tsuboi A et al (1992) Transcriptional activator Tax of HTLV-1 binds to the NF-kappa B precursor p105. Oncogene 7:1737-1742

57. Ohtani K, Iwanaga R, Arai M, Huang Y, Matsumura Y, Nakamura M (2000) Cell type-specific E2F activation and cell cycle progression induced by the oncogene product Tax of human T-cell leukemia virus type I. J Biol Chem 275:11154-11163

58. Ohtani K, Nakamura M, Saito S, Noda T, Ito Y, Sugamura K et al (1987) Identification of two distinct elements in the long terminal repeat of HTLV-I responsible for maximum gene expression. EMBO J 6:389-395 